\title{
ANALISIS HUBUNGAN ANTARA RIWAYAT DIABETES MELLITUS ORANG TUA DENGAN PROFIL GULA DARAH SEWAKTU SISWA SMP DI KOTA PALU TAHUN 2016
}

\author{
Mohammad Aji Purbo, Mayalisa Diantamaela \\ Program Studi Pendidikan Dokter, Fakultas Kedokteran Universitas Alkhairat, Jl. Diponegoro No. 39 \\ Email: dr.mayalisabikusno@gmail.com
}

\begin{abstract}
ABSTRAK
Seseorang yang memiliki riwayat keluarga dengan Diabetes Mellitus tipe 2 memiliki risiko dua sampai enam kali terkena Diabetes Mellitus tipe 2 dibandingkan dengan seseorang yang tidak memiliki riwayat keluarga dengan Diabetes Mellitus. Tujuan penelitian ini adalah untuk mengetahui hubungan antara riwayat Diabetes Mellitus tipe 2 pada orang tua dengan profil gula darah pada anak usia SMP di wilayah Kota Palu tahun 2016. Penelitian ini menggunakan metode observasional, dengan desain penelitian case control. Pengumpulan data dilakukan dengan cara wawancara langsung orang tua siswa dan mengukur kadar glukosa darah sewaktu anak usia siswa SMP. Analisis data diolah menggunakan perangkat lunak SPSS versi 17. Hasil penelitian menunjukkan bahwa riwayat Diabetes Mellitus tipe 2 ayah tidak berhubungan dengan kadar glukosa darah anak usia SMP ( $p$ value 0,388), demikian juga dengan riwayat Diabetes Mellitus tipe 2 pada Ibu tidak berhubungan dengan kadar glukosa darah sewaktu anak usia SMP ( $p$ value 0,446 ). Kesimpulan, tidak terdapat hubungan antara riwayat Diabetes Mellitus tipe 2 orang tua dengan kadar glukosa darah sewaktu anak usia SMP.
\end{abstract}

Kata Kunci : riwayat Diabetes Mellitus tipe 2, risiko riwayat Diabetes Mellitus tipe 2, siswa SMP

\begin{abstract}
A person with type 2 diabetes mellitus family history increase and folding the risk two to six times to suffer from type 2 diabetes mellitus compared to person who does not have. The aim of this study was to determine relationship among parents with history of type 2 diabetes mellitus with children blood sugar profiles as a junior high school students in Palu City in 2016. The case control research design was used in this study, with an observational method. Data collection were done by interviewing parents directly and measuring blood glucose levels of the children in junior high school. Data analysis were processed using software of version 17 SPPS. The results showed that there were no connection among history of parents with type 2 diabetes mellitus compared with blood glucose levels of children in junior high school students ( $p$ value 0.388; $p$ value 0.446, respectively). As conclusion, there is no relationship between histories of parent's type 2 diabetes mellitus and blood glucose levels of children in junior high school students.
\end{abstract}

Keywords: history of type 2 diabetes mellitus, type 2 diabetes mellitus historical risk, junior high school students

\section{PENDAHULUAN}

Diabetes Mellitus adalah penyakit metabolik kronik dengan berbagai etiologi yang ditandai oleh peningkatan kadar glukosa dalam darah yang bersifat kronik disertai gangguan metabolisme karbohidrat, lemak dan protein, gangguan tersebut terjadi akibat gangguan produksi hormon insulin atau gangguan proses kerja hormone insulin maupun keduanya ${ }^{1,2}$.

Penderita Diabetes Mellitus di Dunia mencapai 387 juta dengan prevalensi $8,3 \%$, sedangkan penderita yang tidak terdiagnosis 46.3\%. Prevalensi Diabetes Melitus di Mesir sebesar $15,4 \%$, di USA sebesar $11,4 \%$, di China sebesar 9,3\%, dan di Australia 5,14\%. Prevalensi Diabetes di Indonesia adalah 5,8\% pada tahun $2013^{6}$. Prevalensi tertinggi Diabetes yang paling tinggi menurut diagnosis dokter/gejala hasil Riskesdas tahun 2013 adalah di Provinsi Sulawesi Tengah $(3,7 \%)$. Sedangkan yang terendah ialah di Provinsi Lampung. Prevalensi Diabetes Mellitus di Kota Palu sebesar 1,39\% pada tahun 2012.

Kasus diabetes secara global di kalangan ABG sekitar usia 18 tahun telah meningkat dari 4,7\% pada tahun 1980 menjadi $8,5 \%$ pada tahun 2014. Menurut American Diabetes Association, sekitar 5 ribu orang di bawah usia 20 tahun mendapat diagnosis diabetes tipe 2 setiap tahunnya. Setidaknya 352 juta orang usia muda berisiko terkena diabetes tipe 2. Sebuah penelitian di tahun 2012 yang diterbitkan dalam "Diabetes Care" memperhitungkan potensi jumlah kasus diabetes di masa depan pada orang di bawah usia 20 tahun. Studi ini menemukan bahwa pada saat ini jumlah 
orang di bawah usia 20 tahun dengan diabetes tipe 2 akan meningkat hingga 49 persen pada tahun 2050. Jika tingkat insiden ini terus bertambah, jumlah kasus diabetes tipe 2 pada anak-anak muda bisa meningkat hingga empat kali lipat.

Penelitian yang dilakukan oleh Agus Santosa pada tahun 2017, garis keturunan tidak berhubungan signifikan terhadap usia terdiagnosis diabetes melitus, di usia berapapun bisa terkena diabetes melitus tanpa melihat dari garis keturunan riwayat diabetes, namun riwayat keturunan diabetes dari ibu dan atau ayah+ibu cenderung lebih muda terdiagnosis diabetes walaupun tidak signifikan. Penelitian lain dilakukan oleh John S. Kekenusa pada tahun 2012 di RSUP Prof. Dr. R. D. Kandou Manado. Hasil penelitian tersebut menunjukkan bahwa orang yang memiliki riwayat keluarga menderita DM 5 kali lebih berisiko menderita DM Tipe 2 dibandingkan dengan orang yang tidak memiliki riwayat keluarga menderita DM.

Seseorang yang memiliki riwayat keluarga dengan Diabetes memiliki risiko dua sampai enam kali terkena Diabetes Mellitus tipe 2 dibandingkan dengan seseorang yang tidak memiliki riwayat keluarga dengan Diabetes ${ }^{24}$. Diabetes Mellitus tipe 2 memiliki hubungan yang kuat dengan riwayat keluarga dan garis keturunan dibandingkan dengan Diabetes tipe 1 , meskipun demikian penyakit ini disebabkan oleh pengaruh faktor faktor lain seperti, umur, riwayat keluarga menderita DM, berat badan berlebih, kurangnya aktifitas fisik, dan diet tidak sehat. Pada penelitian terhadap saudara kembar menunjukkan bahwa faktor genetik memiliki peran dalam perkembangan Diabetes Mellitus tipe $2{ }^{25}$. Riwayat keluarga Diabetes tipe 2 dapat meningkatkan risiko anak-anak dan remaja terhadap penyakit Diabetes tipe 2. Obesitas dan riwayat keluarga Diabetes tipe 2 berkaitan dengan peningkatan risiko Diabetes tipe 2 pada remaja, terlepas dari latar belakang etnis/ras ${ }^{26,27}$. Umur dan riwayat keluarga menderita DM termasuk dalam faktor yang tidak dapat dimodifikasi/diubah namun memiliki hubungan yang erat dengan kejadian DM Tipe 2, sehingga dengan mengetahui kedua faktor ini, orang yang berisiko menderita DM Tipe 2 dapat melakukan pencegahan sedini mungkin dan meningkatkan kewaspadaan dengan cara memperhatikan asupan makanan (seperti rendah kalori dan gula) serta melakukan olahraga teratur.

\section{METODE PENELITIAN}

Jenis penelitian ini adalah studi observasional dengan rancangan penelitian case control. Penelitian dilakukan pada bulan Januari sampai Februari 2016, di tempat tinggal siswa SMP. Populasi penelitian ini adalah siswa SMP terpilih di Kota Palu pada tahun ajaran 2015/2016. yaitu SMPN 1 Palu, SMPN 3 Palu, SMPN 9 Palu, dan SMPN 11 Tatanga. Subyek penelitian ini adalah siswa di SMP terpilih di wilayah Kota Palu dan memenuhi kriteria penelitian. Kriteria Inklusi adalah siswa SMP terpilih kelas 1 dan 2, siswa dengan riwayat diabetes Orang Tua, siswa dalam keadaan sehat, siswa laki-laki dan perempuan, siswa dengan umur 13 - 15 tahun, siswa yang orang tuanya penduduk/berdomisili di Kota Palu, dan yang diizinkan oleh orang tuanya tanpa paksaan. Kriteria eksklusi penelitian adalah memiliki penyakit lain yang dapat meningkatkan GDS (Overaktif kelenjar tiroid, chussing sindrom), sedangkan pada orang tua tidak dapat berkomuniksai dengan baik.

Teknik Sampling menggunakan Proportinate Stratified Random Sampling. Pertama dilakukan acak sederhana untuk menentukan kecamatan terpilih, setelah itu random sekolah pada kecamatan terpilih, kemudian random kelas yang pada setiap sekolah terpilih. Lalu random siswa pada kelas terpilih. Total sampel penelitian ini adalah 136 orang siswa SMP. Pengolahan data menggunakan perangkat lunak komputer program SPSS 17.

\section{HASIL}

Penelitian ini dilakukan di SMP 1, SMP 3, SMP 9, SMP 11 pada tahun 2016 terhadap 132 siswa SMP yang dikelompokkan menjadi dua kelompok yaitu siswa yang orang tuanya memiliki riwayat Diabetes dan orang tuanya yang tidak memiliki riwayat Diabetes. Hasil analisa statistik sebagai berikut :

Tabel 1. Hasil analisis hubungan antara riwayat Diabetes orang tua dengan kadar glukosa darah sewaktu siswa SMP.

\begin{tabular}{llcc}
\hline & $\mathbf{N}$ & Rerata \pm s.d & p \\
\hline - Riwayat ayah & $36(26,5 \%)$ & $93,3 \pm 16,6$ & \multirow{2}{*}{0,388} \\
- Tidak ada riwayat Ayah & $100(73,5 \%)$ & $90,3 \pm 15,7$ & \\
\hline - Total & $100(100 \%)$ & & \\
- Tiwayat ibu & $41(30,1 \%)$ & $89,5 \pm 14,5$ & \multirow{2}{*}{0,446} \\
- Total ada riwayat ibu & $95(69,9 \%)$ & $91,7 \pm 15,7$ & \\
\hline
\end{tabular}


Tabel 1 menunjukkan bahwa siswa SMP yang memiliki riwayat diabetes ayah adalah sebanyak 36 orang siswa $(26,5 \%)$ dengan rata-rata kadar glukosa darah sewaktu adalah sebesar 93,3 $\mathrm{mg} / \mathrm{dL}$. Siswa SMP yang tidak memiliki riwayat Diabetes ayah adalah sebanyak 100 orang siswa $(73,5 \%)$ dengan rata-rata kadar glukosa darah sewaktu adalah sebesar 90,3 mg/dL. Dari hasil uji nilai $\mathrm{p}$ ditemukan bahwa faktor ini tidak memiliki hubungan yang bermakna ( $\mathrm{p}=0,388)$.

Siswa SMP yang memiliki riwayat diabetes ibu adalah sebanyak 41 orang siswa $(30,1 \%)$ dengan rata-rata kadar glukosa darah sewaktu adalah sebesar $89,5 \mathrm{mg} / \mathrm{dL}$. Siswa SMP yang tidak memiliki riwayat Diabetes ibu adalah sebanyak 95 orang siswa $(69,9 \%)$ dengan rata-rata kadar glukosa darah sewaktu adalah sebesar $91,7 \mathrm{mg} / \mathrm{dL}$. Dari hasil uji nilai p ditemukan bahwa faktor ini tidak memiliki hubungan yang bermakna $(\mathrm{p}=0,446)$.

Analisis data statistik diperoleh $p$ valuenya adalah 0,388 dan 0,446 yang berarti tidak ada hubungan bermakna antara riwayat diabetes orang tua dengan kadar glukosa darah sewaktu siswa SMP di Kota Palu pada saat penelitian dilakukan. Hal ini mungkin dipengaruhi oleh beberapa faktor antara lain; karena pada siswa yang memiliki orang tua dengan riwayat diabetes maka orang tua memiliki pengetahuan tentang faktor risiko Diabetes Mellitus sehingga gaya hidup keluarga menjadi lebih baik. Hal ini sesuai dengan penelitian Lalu Muhammad Hairi (2013) bahwa penderita Diabetes yang memiliki pengetahuan yang baik tentang Diabetes Mellitus memiliki gaya hidup yang baik, contohnya istirahat yang cukup, aktivitas fisik yang baik dan pola makan yang baik dan sehat. Pengaturan metabolisme kadar glukosa darah pada siswa SMP masih normal sehingga hubungan riwayat diabetes orang tua dengan kadar glukosa darah sewaktu tidak bermakna.

\section{KESIMPULAN}

Dari 68 siswa SMP dengan riwayat Diabetes orang tua dengan 36 siswa dengan riwayat Diabetes ayah, 41 siswa dengan riwayat Diabetes ibu. Hasil penelitian ini, menunjukkan faktor riwayat diabetes ayah tidak memiliki hubungan bermakna dengan kadar glukosa darah sewaktu siswa SMP dengan nilai $p$ adalah 0,388. Dan faktor riwayat Diabetes ibu tidak memiliki hubungan bermakna dengan kadar glukosa darah sewaktu siswa SMP dengan nilai $\mathrm{p}$ adalah 0,446.

\section{DAFTAR PUSTAKA}

CDA. 2013. Type 2 diabetes-the basics. Canadian Diabetes Association Clinical Practice Guidelines. guidelines.diabetes.ca/.../type-2-diabetes-t... Diakses tgl 18-12-2014

ADA. 2012. Diagnosis and Classification of Diabetes Mellitus. Diabetes Care, vol 35, dari: www.oeglmkc.at/labor/ADA-Kriterien2012.pdf. Diakses Tgl. 24-12-2014

IDF. 2014. IDF: Diabetes Atlas 6th Edition Update 2014. International Diabetes Federation. dari:

http://www.idf.org/sites/default/files/Atlasposter-2014_EN.pdf Diakses tanggal 15-082015

Annis AM, Caulder MS, Cook ML, Duquette D. 2005. Family history, diabetes, and other demographic and risk factors among participants of the National Health and Nutrition Examination Survey 1999-2002. Prev Chronic Dis [serial online] 2005 Apr [datecited]. Available from: URL: http://www.cdc.gov/pcd/

issues/2005/apr/04_0131.htm. diakses tanggal 10 oktober 2015

Ada. 2014. Diabetes basic. American Diabetes Assosiation.

Dari

http://www.diabetes.org/diabetes-

basics/genetics-of-diabetes.html?loc $=d b$ slabnav (online) diakses tanggal 10 oktober 2015

Silva A. Arslanian, MD. Fida Bacha, MD. Rola Saad, MD.Neslihan Gungor, MD. 2005. Family History of Type 2 Diabetes Is Associated With Decreased Insulin Sensitivity and an Impaired Balance Between Insulin Sensitivity and Insulin Secretion in White Youth. ADA, Diabetes Care.

http://care.diabetesjournals.org/content/28/1 /115.full.pdf diakses tanggal 10 oktober 2015

Ruth S. Weinstock, Paula M. Trief, Laure El ghormli, Robin Goland, Siripoom McKay, Kerry Milaszewski, Jeff Preske, Steven Willi, and Patrice M. Yasuda. 2015. Parental Characteristics Associated With Outcomes in Youth With Type 2 Diabetes: Results From the TODAY Clinical Trial. Diabetes Care 2015 http://care.diabetesjournals.org/content/38/5/ 784.full.pdf diakses tanggal 10 oktober 2015

Isnaini Nur, Ratnasari. Risk Factors was affects of diabetes mellitus type 2. Jurnal Keperawatan dan Kebidanan Aisyiyah. 2018;14(1), 59-68.

Available from: http://fkm.unsrat.ac.id/wpcontent/uploads/2013/08/GLORIAWUWUNGAN-091511080.pdf

Kekenusa John. S, Ratag Budi. T, Wuwungan Gloria. Analisis Hubungan Antara Umur dan Riwayat Keluarga Menderita DM dengan 
Kejadian Penyakit DM Tipe 2 pada Pasien Rawat Jalan di Poliklinik Penyakit Dalam BLU RSUP PROF. DR. R.D Kandou Manado. Fakultas Kesehatan Masyarakat Universitas Sam Ratulangi Manado. 2013

Available from: http://fkm.unsrat.ac.id/wpcontent/uploads/2013/08/GLORIA-
Santosa Agus, Trijayanto Puput. A, Endiyono. Hubungan Riwayat Garis Keturunan dengan Usia Terdiagnosis Diabetes Melitus Tipe II. The 6thUniversity Research Colloquium 2017. ISSN 2407-9189.

\section{WUWUNGAN-091511080.pdf}

